\title{
Management of Faba Bean Rust by Some Antagonistic Bioagents and Induced Resistance Chemicals
}

\author{
Khairy Abdel-Maksoud Abada ${ }^{1, ~ *, ~ A m a n y ~ M o h a m e d ~ F a r o u k ~ A t t i a ~}{ }^{1}$, \\ Asmaa Mahmoud Abd-Almoaty Alkolaly ${ }^{2}$ \\ ${ }^{1}$ Plant Patholology Department, Faculty of Agriculture, Cairo University, Cairo, Egypt \\ ${ }^{2}$ Integrated Control Research Department, Plant Research Institute, Agriculture Research Centre, Giza, Egypt
}

Email address:

Dr_khairy_abada@yahoo.com (K. Abdel-Maksoud A.)

${ }^{*}$ Corresponding author

\section{To cite this article:}

Khairy Abdel-Maksoud Abada, Amany Mohamed Farouk Attia, Asmaa Mahmoud Abd-Almoaty Alkolaly. Management of Faba Bean Rust by Some Antagonistic Bioagents and Induced Resistance Chemicals. International Journal of Biomedical Materials Research. Vol. 7, No. 1, 2019, pp. 51-60. doi: 10.11648/j.ijbmr.20190701.17

Received: February 15, 2019; Accepted: March 20, 2019; Published: April 29, 2019

\begin{abstract}
Eight bacterial and fungal isolates as well as four induced resistance chemicals (IRCs) were assessed in vitro and in vivo against Uromyces viciae - fabae (Pers.) Schroet, the causal of faba bean rust. The inhibitory effect of Bacillus spp. was ranged between 35.2-50.4\%, Trichoderma spp. between 39.0-59.0\%. and IRCs between 34.3- 57.7\%. In addition, the highest inhibitory effect on the germinated urediospores of the causal fungus was obtained by B. subtilis, T. viride and bion (BTH). Under greenhouse conditions, spraying faba bean plants with any of the tested bioagents significantly reduced disease severity and increased the produced pod yield compared with the control treatment. Also, spraying plants grown from soaked seeds for $12 \mathrm{hrs}$ before sowing in any of the IRCs or soaking in water only with any of these inducers significantly reduced disease severity and increased the produced pod yield compared with the control treatment. Field experiments during two successive seasons under the natural infection by faba bean rust at Behera governorate revealed that spraying $B$. subtilis and T. viride, each alone or in combination, on plants grown from soaked seeds in BTH at beginning of the incidence of the disease significantly reduced disease severity and increased the produced seed yield compared with the control. On the other hand, plants sprayed with the mixture of both bioagents were of the lowest infection and produced the highest dry seeds/plot compared with the other treatments and the control. However, the fungicide Topas was the superior treatment for lowering disease severity and increasing the produced seeds yield. Considerable increase in the activity of three oxidative- reductive enzymes, i.e phenyl alanine ammonia lyase (PAL), peroxidase (PO) and polyphenoloxidase (PPO) in the leaves of all treatments compared with both control treatments. Furthermore, plants grown from seeds soaked in BTH showed the highest activity of the three enzymes followed by those sprayed with B.subtilis then with T.viride.
\end{abstract}

Keywords: Faba-Bean, Bioagents, Disease Management, Induced Resistance Chemicals, Oxidative-Reductive Enzymes, Uromyces Viciae-Fabae, Topas

\section{Introduction}

Faba-bean (Vicia faba L.) is considered one of the most important food legume crops in Egypt. It's economic importance is greatly increased in the world due to its high nutritional value of vitamins, protein, carbohydrates and some other compounds. Thus, it is a rich available source of food for both human and animals [43]. In addition, it is used to improve the soil fertility through nitrogen fixation.
Faba-bean is liable to attack by many bacterial, fungal, viral and nematode diseases in addition to physiological disorder [47]. However, fungal diseases, especially rust caused by Uromyces viciae-fabae (Pers.) Schroet is considered one of the major destructive diseases affecting the crop yield, especially in the north and middle parts of the Delta in Egypt and several countries in the world [1, 37, 47]. Fungicides usually give adequate manage to plant pathogens. but, the continuous use of the fungicides mostly resulted in environmental pollution, disasters all-over the world and the 
causal pathogen become resist to the fungicides. Therefore, in order to overcome these difficulties, it is urgent to use alternative safe materials against such diseases.

Recently, biological control is considered an important approach of agricultural biotechnology for managing many fungal plant pathogens $[14,2,50,6,3,4]$. Trichoderma spp. are the most promising and effective bioagents against many plant pathogenic fungi $[6,18]$. Trichoderma spp. as antagonist for controlling wide range of microbes were well documented and demonstrated fore more than seven decades ago but it's use under field conditions came very later [19], [12]. Their mechanism of mycoparasitism is very complex, it includes nutrient competition, hyperparasitism, antibiosis, and or cell wall degrading enzymes [5]. It was also found that there is a large variety of volatile secondary metabolites produced by Trichoderma spp. such as ethylene, carbon dioxide, hydrogen cyanide, aldehydes and ketones which play an important role in managing many plant pathogens $[50,6]$. Biological control as an effective method for controlling Faba-bean rust to reduce the use of fungicides. Gram-positive Bacillus species [18], however, possess several advantages that make them good candidates for use as plant growth promoting bacteria (PGPB). Firstly, they have also the ability to produce different kinds of antimicrobial compounds, such as (bacilysin, iturin and mycosubtilin), in addition to sidero-phores [45]. Secondly, they are able to induce growth and defence responses in the host plant [41]. In addition, genus Bacillus is able to produce spores resistant to UV light and desiccation, which allows them to resist adverse environmental conditions, and permits easy formulation for commercial purposes [26].

The mechanism of systemic acquired resistance is apparently multifunction, likely resulting in stable broad spectrum disease control and they could be used preventatively to bolster general plant health, resulting in long lasting protection [27].

(Bion) BTH is a systemic acquired resistance elicitor, which reduces many fungal diseases. It has been previously shown that pea rust infection can be reduced by exogenous applications of systemic acquired resistance elicitors such as BTH [7]. This protection is known to be related with the induction of the phenol pathway but the particular metabolites involved have not been determined yet. This suggests fungal growth impairment by both direct toxic effect as well as plant cell wall reinforcement.

This work aimed to the evaluate the inhibitory effect of some Bacillus and Trichoderma spp. on the germination of Uromyces viciae-fabae urediospores in vitro as well as managing fababean rust under greenhouse and field conditions. In addition to, estimation the activity of three oxidative-reductive enzymes, i.e. PAL, PO and PPO in the treated plants with B. subtilis, T. harzianum, BTH and the fungicide Topas.

\section{Materials and Methods}

\subsection{Fungal Pathogen}

Faba-bean leaves bearing the uredial sori of Uromyces viciae-fabae (a virulent isolate) were frequently collected from Nubaria district, Behera governorate, and were used in this study as the fungus Urediospores source.

\subsection{Isolation, Purification and Identification of the Antagonists}

Bacterial and fungal microflora naturally grown on fababean phylloplane were isolated from healthy leaf plants, collected from Nubaria district, Behera governorate using dilution plate technique. Isolates belonging to Bacillus spp. and Trichoderma spp. were selected. Serial dilution plate technique was used to isolate native antagonistics, where Trichoderma spp. were isolated on PDA medium and Bacillus spp. on nutrient agar medium [38].

All the isolated Bacillus spp. were purified and identified as described by [39] and [24], while fungal cultures of Trichoderma spp. were isolated and purified by hyphal tip technique and then identified on the basis of cultural and microscopic morphological characters and using the description of $[42,8]$.

\subsection{Effect of the Tested Bioagents and the IRCs on the Germination of the Urediospores of the Causal Fungus in Vitro}

Flasks $(250 \mathrm{ml}$.) containing nutrient medium were inoculated with a loop-full of the desired bacterial bioagent taken from a two day-old culture. Inoculated flasks were incubated on a rotary shaker at $2000 \mathrm{rpm}$ for 2 days at $28 \pm 1^{\circ} \mathrm{C}$. The culture filtrate was sterilized using a $0.25 \mu \mathrm{m}$ syringe filter.

Also, Trichoderma spp. were grown on gliotoxin fermentation medium (GFM) as described by [10] for 10 days. The culture filtrate was sterilized using a $0.25 \mu \mathrm{m}$ syringe filter. The concentrations of 20,40 and $60 \%$ from the culture filtrate of each of the isolated bioagents were prepared.

The concentrations of $0.0,10,20$ and $40 \mathrm{mM}$ of the IRCs, i.e. Bion (benzothiadiazole; BTH), chitosan (cellulose with the hydroxyl at position $\mathrm{C} 2$ substituted with an acetamido group), saccharin (benzoic sulfimide) as a crystalline compound $\left(\mathrm{C}_{7} \mathrm{H}_{5} \mathrm{NO}_{3} \mathrm{~S}\right)$ and salicylic acid (mono hydroxy benzoic acid were prepared depending on their molecular weight. The urediospores of U.viciae-fabae were brushed from freshly infected faba bean leaves by rust using sterilized camel brush and added to each concentration of the culture filtrate of the tested bioagents and the IRCs.

One $\mathrm{m} 1$. of urediospore suspension $\left(1 \times 10^{2}\right.$ urediospore/ $\mathrm{ml}$ water) was placed on two sterilized slides, put on two glass rods in a sterilized Petri-dish containing a wetted cotton piece by sterilized distilled water to provide high relative humidity. Also, a spore suspension put in distilled sterilized water only was prepared as control. Preparations were incubated in darkness at $25 \pm 1^{\circ} \mathrm{C}$ for 48 hour. Three Petri-dishes for each treatment were used as replicates. The germinated urediospores were counted in a total of 100 urediospores and the averages of the percentages of germination were calculated 
and recorded for each treatment.

\subsection{Effect of the Isolated Bioagents and IRCs on the Severity of Faba-bean Rust under Greenhouse Conditions}

The antagonistic activity of four isolated species of Bacillus (B.chitiosporus, B.megaterium, B.pumilus and B.subtilis) and Trichoderma (T. album, T. hamatum, T. harzianum, and T. viride) as well as the IRCs bion (BTH), chitosan, saccharin and salicylic acid, in addition to the fungicide Topas (penconazole), as check were evaluated for their efficiency in managing faba-bean rust caused by $U$. viciae-fabae (collected from Nubaria district) in pots using artificial inoculation under greenhouse conditions. Two experiments were carried out.

\subsubsection{Effect of the Bioagents}

Five faba-bean seeds (cv. Giza 3) soaked in water for 12 hrs. were sown in each plastic pot $(30 \mathrm{~cm}$ in diameter). The emerged seedlings were thinned into three plants in each pot three weeks after sowing. Plants of two months old were sprayed with suspension of the tested bioagents, i.e. Bacillus spp. $\left(2 \times 10^{6} \mathrm{cfu} / \mathrm{ml}\right.$ water $)$ and Trichoderma spp. $\left(2 \times 10^{3}\right.$ spore suspension/ $\mathrm{ml}$ water) as well as the fungicide Topas EC (tubaconazole) at the rate of $35 \mathrm{ml} / 100$ 1. water. After 72 hrs. the plants were artificially inoculated with $U$. viciaefabae urediospores suspension $\left(2 \times 10^{6}\right.$ spore/ml. water) using sterilized atomizer for each treatment. Control plants, previously sprayed with water only, were sprayed with urediospores suspension of the causal fungus only. Five replicates were prepared for each treatment. All pots were covered with polyethylene bags for $48 \mathrm{~h}$ in a moist chamber at $12-24 \pm 2{ }^{\circ} \mathrm{C}$ in a greenhouse. The bioagents and the fungicide were re-sprayed on the grown plants at the previous rates two weeks after the first spray. The treated plants were examined for disease severity 10 days after each spray with the bioagents and the fungicides and the averages were recorded using the devised scale (0-6) according to [23].

\subsubsection{Effect of the IRCs}

A lot of faba-bean seeds of c.v. Giza-3 was soaked in the tested IRCs (40 mM) for $12 \mathrm{hrs}$ before sowing. Another lot of faba-bean seeds was soaked in water only for the same period. Five seeds from any of the soaked seeds in the IRCs or in water were sown separately in each plastic pot $(30 \mathrm{~cm}$ in diameter). The emerged seedlings were thinned into three plants in each pot three weeks after sowing. The grown plants (two months old) from the soaked seeds in BTH and water were sprayed with the tested IRCs $(40 \mathrm{mM})$ as well as the fungicide Topas $(35 \mathrm{ml} . / 1$. water) one week before artificial inoculation with $U$. viciae-fabae urediospores suspension (2x106 spore/ml. water). Control plants were sprayed with urediospores suspension of the causal fungus only. Five replicates were prepared for each treatment. All pots were covered with polyethylene bags for $48 \mathrm{~h}$ in a moist chamber at $12-24 \pm 2^{\circ} \mathrm{C}$ in a greenhouse. The IRCs and the fungicide Topas were re-sprayed on the grown plants at the previous same rates two weeks after the first spray. The treated plants were examined for disease severity 10 days after each spray with the IRCs and the fungicide and the averages were recorded as mentioned before.

\subsection{Field Experiments}

Field experiments were carried out in Nubaria district, Behera governorate, under flood irrigation system, where severe infection by faba-bean rust is common. The filed was prepared for sowing faba bean (cv. Giza-3) using Herati sowing method during end of October of 2016 and 2017. The filed was divided into plots $(6 \times 7 \mathrm{~m})$ with rows of $70 \mathrm{~cm}$ wide. A lot of faba-bean seeds was soaked in the tested BTH (40 mM) for $12 \mathrm{hrs}$ before sowing. Another lot of faba-bean seeds was soaked in water for the same period. Two seeds from any of the soaked in BTH or in water were sown in each hill at $25 \mathrm{~cm}$ between two hills. All agricultural practices were performed as recommended by Min. of Agric. and Land Recl. The grown plants were left to natural infection by faba-bean rust. The grown plants from seeds soaked in BTH or in water were sprayed with B.subtilis $\left(2 \times 10^{6} \mathrm{cfu} / \mathrm{ml}\right.$ water and T.viride $\left(2 \times 10^{3}\right.$ spore suspension/ $\mathrm{ml}$ water), each alone or in combination in comparison with the fungicide Topas at the first appearance of the disease symptoms. The spray with the tested bioagents and the fungicide Topas was carried out three times with ten days interval.

The treated plants were examined for disease severity 10 days after each treatment using the devised scale by [23] and the averages were recorded. Also, the produced dry pods of each treatment were harvested, threshed, weighted and the average of the dry seeds / plot was recorded.

\subsection{Assessment Disease Severity}

The infected faba-bean plants were carefully examined to assess the severity of the infection by rust depending on the devised scale (0-6) by [23] using the following formula:

$$
\% \text { Disease severity }=\frac{\sum(\mathrm{n} \times \mathrm{v})}{6 \mathrm{~N}} \times 100
$$

Where:

$\mathrm{n}=$ Number of infected leaves in each category.

$\mathrm{v}=$ Numerical values of each category.

$\mathrm{N}=$ Total number of the infected leaves.

\subsection{Statistical Analysis}

Data were statistically analyzed using the standard procedures of complete randomized block, split and split split designs [46]. The averages were compared at 5\% level using least significant differences (L. S. D) according to [21].

\subsection{The Activity of Oxidative-Reductive Enzymes}

Infected faba-bean leaves by rust and uninfected ones were collected from the field of the experiment and used for estimating the activity of the oxidative-reductive enzymes. 
The activity of phenylalanine ammonia lyase (PAL), peroxidase (PO) and polyphenol oxidase (PPO) was measured in leaves of un- infected and infected plants with the causal as well as sprayed with B.subtilis, T. viride, Bion and the fungicide Topas. Samples were collected after one month from the first spray with the different treatments and control plants for enzymes assay. One gram of faba-bean leaves sample was homogenized with $2 \mathrm{ml}$ of $0.1 \mathrm{M}$ sodium phosphate buffer ( $\mathrm{pH}$ 7.0) in ice bath for enzymes assay. The homogenates were then centrifuged at $10.000 \mathrm{rpm}$ for 10 minutes. Supernatants were used to estimate the activity of defense-related enzymes, i.e. PAL, PO, and PPO.

\subsubsection{Activity of PAL}

The activity of phenylalanine ammonia lyase (PAL) was determined according to the method of [11]. The reaction mixture contained $0.03 \mathrm{M}$ L-phenylalanine and $0.2 \mathrm{ml}$ enzyme extract in a total $2.5 \mathrm{ml}$ of sodium borate buffer $(\mathrm{pH}$ 8.8). The mixture was kept in a water bath at $37^{\circ} \mathrm{C}$ for $1 \mathrm{~h}$, and $0.5 \mathrm{ml}$ of $1 \mathrm{M}$ (trichloroacetic acid) TCA was added. The amount of trans-cinnamic acid formed from L-phenylalanine was measured spectrophotometrically at $290 \mathrm{~nm}$. Enzyme activity was expressed as microgram of trans-cinnamic acid $\mathrm{h}^{-1} \mathrm{mg}^{-1}$ protein.

\subsubsection{Activity of PO}

To estimate peroxidase activity (PO), $50 \mu$ of enzyme extract was added to $2.85 \mathrm{ml}$ of $0.1 \mathrm{M}$ phosphate buffer $(\mathrm{pH}$ 7.0) and mixed with $0.05 \mathrm{ml}$ of $20 \mathrm{mM}$ guaiaco reagent [22]. The reaction was started by the addition of $0.02 \mathrm{ml}$ of $40 \mathrm{mM}$ hydrogen peroxide to the mixture. Rate of increase in absorbance at $470 \mathrm{~nm}$ was measured over $1 \mathrm{~min}$. One unit of enzyme activity was defined by the change in absorbance of 0.01 for $1 \mathrm{~g}$ fresh weight.

\subsubsection{Activity of PPO}

The activity of polyphenol oxidase (PPO) was deter-mined according to the method proposed by [32]. The reaction mixture was containing $200 \mu \mathrm{l}$ enzyme extract and $1.5 \mathrm{ml}$ of $0.01 \mathrm{M}$ catechol. Activity was expressed as changes in absorbance at $495 \mathrm{~nm} \cdot \mathrm{min}^{-1} \mathrm{mg}^{-1}$ protein.

\section{Results}

\subsection{Effect of the Tested Bioagents on the Germination of the Urediospores of the Causal Fungus in Vitro}

The effect of the antagonistic bioagents on the germinated urediospores of $U$. vicice-fabae is shown in Tables (1 and 2). Results reveal that all the tested bioagents caused significant reduction to the germinated urediospores of the causal fungus compared with the control. In addition, this decrease was gradually increased by increasing the concentration of the tested treatments.

Data presented in (Table 1) show that the inhibitory effect of Bacillus spp. against $U$. viciae-fabae was in the range of $35.2-51.7 \%$ Urediospores germination, on the average. Moreover, B.subtilis was the most efficient in this respect followed by B.pumilus, where the urediospores failed to germinated at the concentration of $60 \%$. Both $B$. megaterium and $B$. chitinosporus recorded 20.0 and $21.6 \%$ urediospore germination, on the average, at the same concentration, respectively.

The inhibitory effect of Trichoderma spp. against $U$. viciae-fabae was in the range of 39.0- 59.0\% urediospore germination, on the average (Table, 2). The fungus T.viride recorded the highest effect, where the urediospores failed to germinated at the concentration of $60 \%$. T. harzianum then T.album and T. Hamatum recorded 4.8, 30.0 and $32.6 \%$ urediospore germination at the same concentration, on the average, respectively.

Table 1. Effect off four Bacillus spp. On the germinated urediospores of U.viciae-fabae (Nubaria isolate), $48 \mathrm{~h}$ after incubation at $25 \pm 2{ }^{\circ} \mathrm{C}$.

\begin{tabular}{lllll}
\hline \multirow{2}{*}{$\begin{array}{l}\text { Bacillus } \\
\text { bioagents }\end{array}$} & \multicolumn{3}{l}{ \% Uredial germination*at conc. } & \multirow{2}{*}{ Mean } \\
\cline { 2 - 4 } & $\mathbf{2 0}$ & $\mathbf{4 0}$ & $\mathbf{6 0}$ & \\
\hline B.chitinosporus & 81.8 & 49.4 & 20.0 & 50.4 \\
B.megaterium & 83.4 & 50.2 & 21.6 & 51.7 \\
B.pumilus & 77.2 & 39.8 & 0.0 & 42.3 \\
B.subtilis & 73.0 & 32.6 & 0.0 & 35.2 \\
Control & 93.0 & 93.0 & 93.0 & 93.0 \\
Mean & 81.7 & 34.3 & 8.9 & ----- \\
\hline
\end{tabular}

* Initial germination percentage of urediospores was $1.8 \%$.

L.S.D.at5\%for: Bacillus bioagents $(B B)=2.2$, Conc. $(C)=3.9$ andBBxC $=4.2$.

Table 2. Effect of fourTrichoderma spp.on the germinated urediospores of U.viciae-fabae (Nubaria isolate), $48 \mathrm{~h}$ after incubation at $25 \pm 2^{\circ} \mathrm{C}$.

\begin{tabular}{lllll}
\hline \multirow{2}{*}{$\begin{array}{l}\text { Trichoderma } \\
\text { bioagents }\end{array}$} & \multicolumn{3}{c}{ \%Uredial germination at conc. } & \multirow{2}{*}{ Mean } \\
\cline { 2 - 4 } & $\mathbf{2 0}$ & $\mathbf{4 0}$ & $\mathbf{6 0}$ & \\
\hline T.album & 84.6 & 56.4 & 30.0 & 57.0 \\
T.hamatum & 86.4 & 58.0 & 32.6 & 59.0 \\
T.harzianum & 80.8 & 45.4 & 4.8 & 43.7 \\
T.viride & 78.2 & 40.4 & 0.0 & 39.0 \\
Control & 91.6 & 91.6 & 91.6 & 91.6 \\
Mean & 83.0 & 50.4 & 31.8 & ---- \\
\hline
\end{tabular}

Initial germination percentage of urediospores was $1.4 \%$.

L.S.D.at5\%for:Trichoderma bioagents $(\mathrm{TB})=2.8$, Conc. $(\mathrm{C})=3.1$ and $\mathrm{TBxC}=$ 4.3.

\subsection{Effect of Four IRCs on the Germination of Urediospores of the Causal Fungus in Vitro}

Results (Table 3) reveal that the tested IRCs resulted in significant reduction to the germinated urediospores of the causal fungus in the range of $34.3-62.7 \%$ uredial germination, on the average, compared with to the control (92.6\%, on the average).

In addition, BTH was the most efficient one in this regard, where the urediospores failed to germinate at the concentration of $40 \mathrm{mM}$. It recorded $34.3 \%$ uredial germination, on the average followed by salicylic acid then chitosan, being 37.2 and $40.9 \%$ uredial germination, on the average, respectively. Meanwhile, saccharin was the lowest efficient one, being $62.7 \%$ uredial germination, on the average. The inhibitory effect of the tested IRCs was gradually increased by increasing the concentration. 
Table 3. Effect of different IRCs on the germination of urediospores of U.viciae-fabae (Nubaria isolate), $48 \mathrm{~h}$ after incubation at $25 \pm 2^{\circ} \mathrm{C}$.

\begin{tabular}{lllll}
\hline \multirow{2}{*}{ IRCs } & \multicolumn{3}{c}{ \%Uredial germination at conc. of $(\mathbf{m M})$} & \multirow{2}{*}{ Mean } \\
\cline { 2 - 4 } & $\mathbf{2 0}$ & $\mathbf{4 0}$ & $\mathbf{6 0}$ & \\
\hline Bion(BTH) & 64.4 & 38.4 & 0.0 & 34.3 \\
Chitosan & 69.4 & 43.8 & 9.6 & 40.9 \\
Saccharin & 85.0 & 64.4 & 38.8 & 62.7 \\
Salicylic acid & 66.4 & 40.2 & 5.0 & 37.2 \\
Control & 92.6 & 92.6 & 92.6 & 92.6 \\
Mean & 75.6 & 55.9 & 29.2 & ---- \\
\hline
\end{tabular}

Initial germination percentage of urediospores was $1.6 \%$.

L.S.D.at 5\%for: IRCs $(I)=2.7$, Concentrations $(C)=3.3$ and $E x C=3.1$.

\subsection{Effect of the Tested Bioagents and IRCs on the Severity of Faba-bean Rust under Greenhouse Conditions}

\subsubsection{Effect of the Bioagents}

Spraying faba bean plants of two months old with any of the tested bioagents $72 \mathrm{hrs}$ before inoculation with the urediospores of U.viciae-fabae significantly reduced rust severity under greenhouse conditions (Table, 4). The severity of the disease after inoculation with Bacillus spp. was in the range of $9.1-11.1 \%$, Trichoderma spp. in the range of 10.2 $12.0 \%$ and the fungicide Topas $2.4 \%$ compared with the control treatment $(31.6 \%)$.

Also, all the tested bioagents and the fungicide Topas resulted in significant increase to the number of pod and their weight/plant compared with the control treatment. The fungicide Topas resulted in the highest values of number of pods and their dry seeds weight/plant. In addition, Bacillus spp. were most efficient in this regard than Trichoderma spp.

Table 4. Effect of spraying different antagonistic biagents on the severity of faba-bean rust (cv.Giza3) as well as number of pods and dry seeds weight/plant under greenhouse condition.

\begin{tabular}{llll}
\hline $\begin{array}{l}\text { Bacterial and } \\
\text { Fungal bioagents }\end{array}$ & $\begin{array}{l}\text { \%Disease } \\
\text { severity }\end{array}$ & $\begin{array}{l}\text { No. of } \\
\text { pods/plant }\end{array}$ & $\begin{array}{l}\text { Dry seeds } \\
\text { yield(g)/plant }\end{array}$ \\
\hline B.chitinosporus & 11.1 & 22.8 & 119.0 \\
B.megaterium & 10.6 & 23.0 & 121.2 \\
B.pumilus & 10.0 & 24.0 & 122.8 \\
B.subtilis & 9.1 & 26.4 & 128.8 \\
T.album & 12.0 & 25.0 & 110.0 \\
T.hamatum & 11.7 & 23.8 & 117.8 \\
T.harzianum & 11.3 & 22.0 & 120.2 \\
T.viride & 10.2 & 22.3 & 123.8 \\
Topas & 2.4 & 31.0 & 151.2 \\
Control & 31.6 & 18.4 & 54.1 \\
L.S.D.at5\% & 2.7 & 2.9 & 3.3 \\
\hline
\end{tabular}

\subsubsection{Effect of the IRCs}

Data presented in Table (5) show the effect of spraying the tested IRCs, i.e. BTH, chitosan, saccharin and salicylic acid on faba-bean plants grow from seeds soaked in BTH or water on the severity of the infection by the tested pathogen and the produced pods and their dry seeds yield.

Table 5. Effect of soaking faba bean seeds in different IRCs or spraying them on the plants on the grown plants on the severity of rust(cv.Giza3) as well as number of pods and dry seeds weight/plant under greenhouse condition.

\begin{tabular}{|c|c|c|c|c|c|c|c|c|c|}
\hline \multirow{2}{*}{ Treatments } & \multicolumn{3}{|c|}{ \%Disease severity of } & \multicolumn{3}{|c|}{ No. of pods/plant of } & \multicolumn{3}{|c|}{ Dry seed yield(g)/plant of } \\
\hline & Soaking & Spraying & Mean & Soaking & Spraying & Mean & Soaking & Spraying & Mean \\
\hline Bion & 6.2 & 12.4 & 9.3 & 30.8 & 24.8 & 27.8 & 129.0 & 121.4 & 125.2 \\
\hline Chitosan & 8.1 & 12.7 & 10.9 & 25.8 & 21.6 & 23.7 & 113.2 & 119.0 & 116.1 \\
\hline Saccharin & 9.4 & 14.5 & 12.0 & 25.0 & 22.8 & 23.9 & 112.2 & 118.2 & 115.2 \\
\hline Salicylic acid & 7.6 & 12.4 & 10.0 & 31.4 & 25.4 & 28.4 & 120.2 & 119.6 & 119.7 \\
\hline Topas & 1.2 & 2.1 & 1.7 & 34.0 & 27.0 & 30.5 & 159.8 & 141.8 & 140.5 \\
\hline Control & 20.8 & 31.6 & 26.2 & 23.4 & 18.4 & 20.9 & 128.8 & 54.1 & 91.5 \\
\hline $\operatorname{Treatment}(\mathrm{T})=$ & 2.6 & & & 2.9 & & & 3.5 & & \\
\hline Soak.\&Spra. $(\mathrm{S})=$ & 3.2 & & & 3.6 & & & 2.3 & & \\
\hline $\mathrm{TXS}=$ & 4.0 & & & 3.9 & & & 4.7 & & \\
\hline
\end{tabular}

Results indicate that the tested IRCs resulted in significant reduction to the infection by the causal fungus with considerable increase in the produced pods and the weight of their dry seeds yield compared with the control. In addition, the lowest values of the infection by the causal fungus and the highest values of the No. of pods and their dry seeds yield/ plant were recorded for plants grown from seeds soaked in the tested IRCs and sprayed with these inducers (8.9\% disease severity,28.4 pod and 127.2 g. dry seeds / plant, on the average, respectively) compared with those grown from seeds soaked in water only and sprayed with these inducers (14.3\% disease severity, 23.2 pod and $112.4 \mathrm{~g}$. dry seeds / plant, on the average, respectively). However, the fungicide Topas was the superior treatment for reducing the infection and increasing No. of pods and their dry seeds yield/ plant, being $1.7 \%$ disease severity, 30.5 pod and 140.5 g dry seeds / plant, on the average.

\subsection{Field Experiments}

Results (Tables 6 and 7) indicate that field experiments revealed that spraying B.subtilis and T.viride, each alone or in combination on faba bean plants grown from soaked seeds in BTH and un-soaked (soaked in water only) at beginning of the incidence of the disease symptoms significantly reduced the severity of the disease with significant increase to the produced dry seeds yield compared with the control. In addition, plants sprayed with the mixture of both bioagents were of the lowest infection by rust (5.9\%) and produced the highest dry seeds / plot (10.0 kg.) compared with the control $(41.8 \%$ infection and $6.7 \mathrm{~kg}$. dry seeds / plot), as well as spraying each of them alone. However, the fungicide Topas 
was the superior treatment for lowering the severity of the $\mathrm{Kg} . \mathrm{plot})$. disease $(3.6 \%)$ and increasing the produced seed yield (11.1

Table 6. Effect of spraying the antagonistic biagents B.subtilis and T.viride, each alone or in combinations, on faba-bean plants grown from seeds soaked in BTH or in water compared with the fungicide Topas on the severity of rust (cv.Giza-3) under field conditions during $2016 / 2017$ and 2017 / 2018 growing seasons at Nubaria district, Behera governorate.

\begin{tabular}{|c|c|c|c|c|c|c|c|}
\hline \multirow{3}{*}{ Treatments } & \multicolumn{4}{|c|}{ \%Disease severity of plants grown(during)from seeds } & \multirow{2}{*}{\multicolumn{2}{|c|}{ Mean }} & \multirow{3}{*}{$\begin{array}{l}\text { General } \\
\text { mean }\end{array}$} \\
\hline & \multicolumn{2}{|c|}{$2016 / 2017$} & \multicolumn{2}{|l|}{$2017 / 2018$} & & & \\
\hline & Soaked in BTH & Soaked in water & Soaked in BTH & Soaked in water & Soaked in BTH & Soaked in Water & \\
\hline B.subtilis (BS) & 5.2 & 15.1 & 5.8 & 15.4 & 5.5 & 15.3 & 10.4 \\
\hline T.viride(TV) & 5.4 & 16.2 & 6.1 & 16.8 & 5.8 & 16.5 & 11.2 \\
\hline $\mathrm{BS}+\mathrm{TV}$ & 3.1 & 8.3 & 3.4 & 8.7 & 3.3 & 8.5 & 5.9 \\
\hline Topas & 1.7 & 5.1 & 1.8 & 5.4 & 1.8 & 5.3 & 3.6 \\
\hline Control(infected) & 25.0 & 57.2 & 26.4 & 58.4 & 25.7 & 57.8 & 41.8 \\
\hline Mean & 8.1 & 20.4 & 8.7 & 20.9 & 8.4 & 20.7 & --- \\
\hline General mean & 14.3 & & 14.8 & & ---- & ----- & ------ \\
\hline
\end{tabular}

L.S.D.at $5 \%$ for: Treatments $(\mathrm{T})=2.3$, Soaking $(\mathrm{S})=4.7$, $\mathrm{Year}(\mathrm{Y})=$ n.s., $\mathrm{TxS}=3.1, \mathrm{Tx} Y=2.8, \mathrm{Sx} Y=3.6 \operatorname{and} \mathrm{TxSx} Y=4.5$.

Table 7. Effect of spraying the antagonistic biagents B.subtilis and T.viride, each alone or in combinations, on faba-bean plants grown from seeds soaked in BTH or in water compared with the fungicide Topas on the produced seeds yield under field conditions during 2016/2017 and 2017 / 2018 growing seasons at Nubaria district, Behera governorate.

\begin{tabular}{|c|c|c|c|c|c|c|c|}
\hline \multirow{3}{*}{ Treatments } & \multicolumn{4}{|c|}{ Average of dry seeds yield $\mathrm{kg} / \mathrm{plot}\left(42 \mathrm{~m}^{2}\right)$ of seeds } & \multirow{2}{*}{\multicolumn{2}{|c|}{ Mean }} & \multirow{3}{*}{$\begin{array}{l}\text { General } \\
\text { mean }\end{array}$} \\
\hline & \multicolumn{2}{|c|}{$2016 / 2017$} & \multicolumn{2}{|l|}{$2017 / 2018$} & & & \\
\hline & Soaked in BTH & Soaked in water & Soaked in BTH & Soaked in water & Soaked in BTH & Soaked in Water & \\
\hline B.subtilis (BS) & 10.2 & 8.3 & 10.1 & 8.2 & 10.2 & 8.2 & 9.2 \\
\hline T.viride (TV) & 9.9 & 8.5 & 9.8 & 8.3 & 9.7 & 8.4 & 9.0 \\
\hline $\mathrm{BS}+\mathrm{TV}$ & 10.7 & 9.2 & 10.6 & 9.1 & 10.6 & 9.2 & 9.9 \\
\hline Topas & 11.9 & 10.4 & 11.6 & 10.3 & 11.8 & 10.3 & 11.1 \\
\hline Control(infected) & 7.8 & 5.7 & 7.6 & 5.6 & 7.7 & 5.6 & 6.7 \\
\hline General mean & 9.2 & & 9.7 & & ----- & ----- & ----- \\
\hline
\end{tabular}

L.S.D. at $5 \%$ for: Treatments $(\mathrm{T})=3.4$, Soaking $(\mathrm{S})=5.3$, Year $(\mathrm{Y})=\mathrm{n} . \mathrm{s}$., $\mathrm{TxS}=3.7, \mathrm{TxY}=3.1, \mathrm{SxY}=4.2$ and $\mathrm{T} x \mathrm{~S} x \mathrm{Y}=4.8$.

\subsection{Activity of Three Oxidative-Reductive Enzymes}

Table 8 shows the changes in the activity of oxidativereductive enzymes, i.e. phenylalanine ammonialyase (PAL), peroxidase $(\mathrm{PO})$ and polyphenoloxidase (PPO) in faba-bean leaves due to spraying the plants with two bioagents, i.e. B.subtilis and T.viride as well as the IRC BTH and the fungicide Topas compared with the untreated two controls (infected and un-infected).

Data reveal that, in general, the three enzymes, i.e. PAL, PO and PPO were greatly increased in the leaves of all sprayed treatments compared with both control treatments. In addition, plants sprayed with BTH signalized the highest activity of the three enzymes, being $0.589,0.482$ and 0.712 , respectively followed by those sprayed with B.subtilis, being $0.591,0.454$ and 0.670 . respectively then by T.viride, being $0.583,0.450$ and 0.665 , respectively. Meanwhile, untreated plant leaves of un-infected plants and infected plants recorded the lowest activity, being $0.538,0.394$ and for uninfected plants and 0.545 and $0.558,0.409$ and 0.587 , for infected plants, respectively followed by those sprayed with the fungicide Topas, being $0.579,0.443$ and 0.628 , respectively.

Table 8. Effect of spraying faba bean plants with two bioagents and BTH in comparison with the fungicide Topas on the activity of oxidative-reductive enzymes.

\begin{tabular}{llll}
\hline \multirow{2}{*}{ Treatments } & Activity of* & & Polyphenol-oxidase(PPO) \\
\cline { 2 - 4 } & Phenylalanine ammonialyase (PAL) & Peroxidase(PO) & 0.670 \\
\hline B.subtilis & 0.591 & 0.454 & 0.665 \\
T.viride & 0.583 & 0.450 & 0.712 \\
BTH & 0.609 & 0.482 & 0.628 \\
Topas & 0.579 & 0.443 & 0.545 \\
Control(Uninfected) & 0.538 & 0.394 & 0.587 \\
Control(Infected) & 0.558 & 0.409 & \\
\hline
\end{tabular}

*Expressed as absorption after 30 sec. at appropriate wave length and the activity of PAL, PO and PPO at zero time were 0.220,0.244 and 0.350, respectively.

\section{Discussion}

With increasing public awareness of the environmental implications of the use of large quantities of fungicides in agricultural practices, alternative strategies for the control of plant disease are being sought as integrated control [30], [17]. Nowadays, biological control using antagonistic microbes alone, or in combination with another supplements 
to minimize the use of chemicals in a system of integrated plant disease management, has become more important.

Protection of plants from the diseases by induction of systemic acquired resistance is a new approach. This is much less harmful to the environment as compared to deadly agrochemicals applied to control plant diseases [28]. It has been mentioned that Bacillus-based biological control agents (BCAs) have great potential in integrated pest management (IPM) systems [26]; however, relatively little work has been published on integration with other IPM management tools [30]. Unfortunately, most researches have focused on BCAs as alternatives to synthetic chemical fungicides or bactericides and not as part of an integrated management system. In addition, induced systemic resistance was observed in tomato against late blight, caused by Phytophthora infestans (Mont.) with B. pumilus strain SE34n that was incorporated into the potting medium [49].

The antagonistic isolates of both Bacillus spp. and Trichoderma spp. inhibited the germinated urediospores of $U$. viciae-fabae in the range of $35.2-51.7 \%$ and $39.0-59.0 \%$, respectively. In addition, both B.subtilis and T. viride gave the highest inhibition. This may be due to the release of toxic metabolites into the medium [15], [50],[6]. The antagonistic nature may be due to antibiosis, nutrient competition and cell wall degrading enzymes.

Trichoderma spp. are known to control pathogens either indirectly by competing for nutrients and space, modifying the environmental conditions, or promoting plant growth and enhancing plant defensive mechanisms and antibiosis, or directly by inhibition of growth and sporulation of the pathogen mechanisms such as mycoparasitism and enzyme production [51], [9]. The obtained data revealed in vitro that non-volatile secondary metabolites of Trichoderma species were effective in suppressing the germinated urediospores of U.viciae-fabae. In addition, T. viride exhibited the highest effect in this regard followed by T. harzianum after $48 \mathrm{hrs}$. of confrontation.

Greenhouse experiments indicated that, spraying fababean plants (two months old), grown from seeds soaked in BTH or in water,72 hrs before inoculation with the tested pathogen with any of the tested species of genera Bacillus and Trichoderma significantly reduced rust severity compared with the control. Both B.subtilis and T.viride were the highest antagonistic bioagents in reducing the infection by the causal fungus and increasing No. of pods and dry seeds yield/ plant compared with the other bioagents and the control. This may be due to their effect on germ-tube elongation and to a lesser extension of germination rate [51].

The obtained results showed that both B.subtilis and $T$. viride exhibited maximum inhibition to the germinated urediospores of the causal fungus. It appears that despite the absence of direct contact between Trichoderma spp. and U.viciae-fabae, the first may have an inhibitory activity on the germination process of the pathogen. This could be explained by the ability of Trichoderma spp. to produce volatile and non-volatile substances that are able to limit and even stop the germinated urediospores of the pathogen. Also, it is found that there is large variety of volatile secondary metabolites produced by Trichoderma spp. such as ethylene, carbon dioxide, hydrogen cyanide, aldehydes and ketones, which play an important role in managing the plant pathogens [48, 40, 50, 6].

It is worth to mention that the basic principle for the success of a biological control program is a good adaptation of a given bioagent to the local environmental conditions in which it is supposed to work. The obtained data revealed that there was a promising antagonistic species of Bacillus spp. and Trichoderma spp. prevalent on faba-bean leaves, which could be exploited for the control of rust.

Field experiments revealed that spraying B.subtilis and T.viride. each alone or in combination, on faba-bean plants grown from soaked seeds in BTH at beginning of the incidence of the disease symptoms significantly reduced the severity of the disease with significant increase to the produced yield of dry seeds compared with the control. In addition, the fungicide Topas was the superior treatment for lowering the severity of the disease and increasing the produced seed yield followed by spraying the mixture of both bioagents.

BTH was used to induce resistance in bean against rust caused by Uromyces appendiculatus. Histochemical and cytochemical investigations showed that BTH causes hydrogen peroxide $\left(\mathrm{H}_{2} \mathrm{O}_{2}\right)$ accumulation in the treated tissues. $\mathrm{H}_{2} \mathrm{O}_{2}$ deposits were localized in situ for the first time in the apoplast of the leaf epidermis. No cell death was detected at BTH concentrations below the phytotoxicity threshold, suggesting that acquired resistance against bean rust is mainly related to the enhanced activity of anionic peroxidases, promoted by $\mathrm{H}_{2} \mathrm{O}_{2}$ accumulation, thereby leading to cell wall strengthening. This hypothesis is also supported by the long induction phase required to establish complete resistance [25].

Significant reduction in rust incidence and severity of faba-bean under field trials was achieved using integrated treatment application of chemical inducers with the bioagent T. harzianum [18]. However, unlike elicitors of phytoalexines accumulations, which are elicited at the site of application may be responsible for localized protection and induces systemic acquired resistance that sensitizes the plant response rapidly after infection[31]. These responses induced phytoalexines accumulation and lignifications and induce enhance activities of chitinase and $\beta$-glucanase [13], [34. [16] mentioned that induced acquired resistance is persistent and generally is pathogen nonspecific. Furthermore, various chemicals have been considered for their potential to induce defense responses in plants, such as, 6-dichloroisonicotinic acid (INA), $\beta$-aminobutyric acid (Bion) and salicylic acid [36].

Pathogenicity-related proteins are usually quantified to assess the activation of defense system of plants. Plants treated with the two bioagents, BTH and the fungicide Topas showed an increase in PAL, PO and PPO activity compared with control treatment. It is well known that PPO is a copper containing enzyme, which is responsible for oxidization of 
phenolics to highly toxic quinines. This enzyme is also involved in terminal oxidation of diseased plant tissue, and this role of this enzyme is attributed in disease resistance [29] On the other hand, PAL is the main enzyme in phenyl propanoid pathway and flavonoid pathway [44] and peroxidase enzyme is related with more than one function in plants. In addition, plants sprayed with BTH recorded the highest activity of the three enzymes followed by those treated with T.viride and B.subtilis. It has been found that the reduction in disease severity was attributed to the increased levels of PAL, PO and PPO enzymes.

Peroxidase enzyme oxidizes the phenols to more fungal toxic compounds such as quinines, which inhibit both spore germination and fungal growth. Also, peroxidase was found to be participate in the synthesis of lignin [20], [35]. Moreover, the participation of an endogenous supply of phenolic compound in the plant disease resistance is dependent upon active phenol oxidase system [33].

\section{Conclusion}

This study showed that there are promising antagonistic species of bacteria and fungi prevalent on faba-bean leaves, which could be exploited for management of rust. The genera Bacillus and Trichoderma comprise a great number of bacterial and fungal strains that act as bioagents for the control of plant diseases and for their ability to increase plant growth, the antagonistic properties of which are based on the activation of multiple mechanisms. The present study clearly showed the effect of the two antagonistic strains of Bacillus and Trichoderma isolates against the germinated urediospores of the causal fungus. The non-volatile compounds produced by the selected Bacillus and Trichoderma spp. drastically reduced the germinated urediospores of the causal fungus in vitro and resulted in great reduction to faba-bean rust with considerable increase to the produced seed yield. Based on the present investigation a new strategy will be developed for managing rust disease on faba bean in vivo.

\section{Abbreviations}

IRCs, induced resistance chemicals; IPM, integrated pest management; BTH, benzothiadiazole; LSD, least significant differences; IPM, integrated pest management; BCAs, biological control agents; SAR, systemic acquired resistance; SA, salicylic acid; PR, pathogenesis-related; ISR, induced systemic resistance; PAL, phenyl alanine ammonia lyase; PO, peroxidise and PPO, polyphenol oxidase

\section{References}

[1] Abada, K. A.; Mostafa, M. A; Hewidy, M. A. and Sarhan, E. A. D. (2003). Completing the life cycle of Uromyces vicia fabae on faba-bean plants in Egypt. $10^{\text {th }}$. Cong. of Phytopathol., Giza, Egypt,9-10 December, 53-62.
[2] Abada, K. A. and Eid, Kh. E. (2013). A Protocol suggested for management of cantaloupe downy mildew. J. of App. Sci. Res., 9(11): 5633-5642.

[3] Abada, K. A. and Attia, Amany M. F. (2017). Potentiality of induce resistante chemicals and bioagents in managing lettuce downy mildew. Amer. J. of BioSci., 5(1): 4-12.

[4] Abada, K. A.; Attia, Amany M. F. and Youssef, Maryan M. (2018). Role of chemicals for plant resistance, Trichoderma bioagents and cow whey milk in combination on management of tomato powdery mildew. J. of Biotechnol. and Bioeng., 2(2):1-11

[5] Abd-El-Khair, H. R.; Khalifa, K. M.; Hagg, Karima H. E. (2010). Effect of Trichoderma spp. on damping off diseases incidence, some plant enzymes activity and nutritional status of bean plants. J. of Amer. Sci., 6 (9):486-497.

[6] Barakat, F. M.; Abada, K. A.; Abou-Zeid, N. M. and ElGammal, Y. H. E.(2014). Effect of volatile and non-volatile compounds of Trichoderma spp. on Botrytis fabae the causative agent of Faba-bean chocolate spot. Amer. J. Life Scis., 2(6-2):11-18.

[7] Barilli, E.; Diego, R.; Carmine, A.; Antonio, E. and Prats, Elena. (2015). BTH and BABA induce resistance in pea against rust (Uromyces pisi) involving differential phytoalexin accumulation. Planta, 242 (5): 1095-1106. doi: 10.1007/s 00425- 015-2339-8.

[8] Bissett, J. (1991). A revision of the genus Trichoderma. W: Infragenic classification. Can. J. Bot., 69:2317-2357.

[9] Bouhassan, A.; Sadiki, M. and Tivoli, B. (2004). Evaluation of a collection of faba bean (Vicia fabae L.) genotypes originating from the Maghreb for resistance to chocolate spot (Botrytis fabae) by assessment in the field and laboratory. Euphytica, 135:55-62.

[10] Brain, P. W. and Hemming, H. G. (1945). Gliotoxin a fungistatic metabolic product of Trichoderma viride. Ann. Appl. Biol., 32: 214- 220.

[11] Burrell, M. M. and Rees, T. A. (1974). Metabolism of phenylalanine and tyrosine in rice leaves infected by Pyricularia oryzae. Physiol. Plant Pathol., 4: 497-508.

[12] Chet, I.; Inbar, J. and Hadar, I. (1997). Fungal antagonists and mycoparasites. In: The Mycota IV: Environmental and Microbial Relationships. Wicklow D. T. and Soderstorm B., eds. pp 165-184.

[13] Dean, R. A. and Kuc, J. (1985). Induced systemic protection in plants. Trends Biotechnol., 3: 125-128.

[14] Deshmukh, A. J.; Mehta,. B. P. and Patil, V. A. (2010). In vitro evaluation of some known bioagents to control $C$. gloeosporioides Penz, and Sacc, causing anthracnose of Indian bean. Int. J. Pharma and Bio. Sci., 1 (2): 1-6

[15] Dubos, B. and Bulit, J. (1981). Filamentous fungi as biocontrol agents on aerial plant surfaces Ill: BlackmanJ. P. (ed). Microbial Ecology of the phylloplane. Academic Press, London, pp 353-356.

[16] Doubrava, N.; Dean R. and Kuc, J. (1988). Induction of systemic resistance to anthracnose caused by Colltetrichum lagenarum from spinach and hubar leaves. Physiol. Mol. Plant Pathol., 33: 60-70. 
[17] Ellis, R. J.; Timms-Wilson, T. M.; Beringer, J. E.; Rhodes, D.; Renwick, A.; Stevenson, L. and Bailey, M. J. (1999). Ecological basis for biocontrol of damping-off disease by Pseudomonas fluorescens 54/96. J. App. Microbiol., 87:454 463.

[18] El-Mogy, Nehal S. and AbdelKader, M. M. (2018). Bio- and fungicide alternatives treatments for suppressing faba bean rust disease under natural field conditions. Biosci. Res., 15(2):1415-1423.

[19] Fahim, M. M.; Attia, M. F.; Okasha. A. K. and Abada, K. A. (1987). Trichoderma as a biocontrol agent against root and crown-rots of strawberry. Egypt. J. Phytopathol., 21 (2): 139148 .

[20] Farkas, L. and Kiraly, L. (1967). Role of phenolic compounds in the physiology of plant disease and disease resistance. Phytopathol. Z., 40: 106-150

[21] Fisher, R. A. (1948). Statistical Methods for research workers $\left(10^{\text {th }}\right.$ ed.). Oliver 8: Boyd, Edinburgh.

[22] Fu, J. and Huang, B. (2001). Involvement of antioxidants and lipid peroxidation in the adaptation of two cool-season grasses to localized drought stress. Environ Exp. Bot., 45(2):105-114.

[23] Godoy, C. V.; Carneiro, S. M. T. B. G.; Iamauti, T.; Amorim, L.; Berger, R. D. and Bergamin, F. A. (1997). 4: 336-45.

[24] Bergey, D. H.; Holt, J. G. and Krieg, N. R. (1984). Bergey's Manual of Systematic Bacteriology. Baltimore, MD: Williams \& Wilkins, (C1984-(C1989 Diagrammatic scales for bean diseases: development and validat-ion. Zeitschriftfür Pflanzenkrankheiten und Pflanzens-chutz, Oriology. Williams \& Wilkins, Baltimore, USA.

[25] Iriti, M. and Faoro, F. (2003). Benzothiadiazole (BTH): Induces cell-death independent resistance in Phaseolus vulgaris against Uromyces appendiculatus. J. of Phytopathol., 151(3): 171-180.

[26] Jacobsen, B. J.; Zidack, N. K. and Larson, B. J. (2004). The role of Bacillus-based biological control agents in integrated pest management systems: Plant Diseases. Phytopathology, 94(11):1272-1275.

[27] Kessmann, H.; Sataub, T.; Hofmann, C.; Meatzke, T. and Herzog, J. (1994). Induction of systemic acquired disease resistance in plants by chemicals. Ann. Rev. Phytopathol., 32: 439-459.

[28] Kloepper, J. W.; Ryu, C. M. and Zhang, S. (2004). Induced systemic resistance and promotion of plant growth by Bacillus spp. Phytopathology, 94(11):1259-1266.

[29] Kosuge, T. (1996). The role of phenolics in host response to infection to infection. Ann. Rev. Phyto-pathol., 7:195-222.

[30] Kumar, R. N and Mukerji, K. G. (1996). Integrated disease management future perspectives, pp. 335-347. In: K. G. Mukerji, B. Mathur, B. P. Chamala and C. Chitralekha (Eds.), Advances in Botany. APH Publishing Corporation, New Delhi.

[31] Larcke, P. (1981). Alternative chemical agents for controlling plant diseases. Phil. Trans. Res. Soc., 2: 83- 101.

[32] Mayer, A. M.; Harel, E. and Shaul, R. B. (1965). Assay of catechol oxidase a critical comparison of methods. Phytochemistry, 5:783-789.
[33] Melo, G. A.; Shimizu, M. M. and Mazzafera, P. (2006). Polyphenoloxidase activity in coffee leaves and its role in resistance against the coffee leaf miner and coffee leaf rust. Phytochemistry, 67: 277-285.

[34] Metranx, J. D. and Boller, T.(1986). Local and systemic induction of chitinase in cucumber plants in response to fungal, bacterial and viral infections. Physiol. Mol. Pathol., 28: 161-169.

[35] Morkunas, I. and Gemerek J. (2007). The possible involvement of peroxidase in defense of yellow lupine embryo axes against Fusarium oxysporum. J. Plant Physiol., 164: 497506.

[36] Musloco, A.; Felicim, M.; Concheri, G. and Nardi, S. (1993). Effect of earthworm humic substances on esterase and peroxidase activity during growth of leaf explants of Nicotiana plumbaginifolia. Biol. and Ferti. of Soils, 15, 127 131.

[37] Nassib, A. M.; Khalil, S. A., El-Botai,. M. A. and Radi, M. M. (1991). In: Nile Valley Regional program on Cool Season Food Legumes and Cereals. 1990/91. Annual Report, Egypt. Cairo: ARC /ICARDA.

[38] Oedjijono, M. A. L. and Dragar, C. (1993). Isolation of bacteria antagonistic to a range of plant pathogenic fungi. Soil Biol. Biochem., 25: 247-250.

[39] Parry, J. M.; Turnbull P. C. B. and Gibson J. R. (1983). A colour atlas of Bacillus species, Wolfe Medical Publications Ltd. 390 -396.

[40] Prasad, B. N. and Kumar, M. R. (2011). Effect of non-volatile compounds produced by Trichoderma spp. on growth and sclerotial viability of Rhizoctonia solani, incident of sheath blight of rice. Indian J. Funda. App. Life Sci.,1 (2) 37-42.

[41] Raupach, G. S. and Kloepper, J. W. (1998). Mixtures of plant growth promoting rhizobacteria enhance biological control of multiple cucumber pathogens. Phytopathology, 88:1158-1164.

[42] Rifai, M. A. (1969). A revision of the genus Trichoderma. Mycological Papers, 116:1-56

[43] Sahile, S.; Sakhuja, P. K.; Fininsa, C. and Ahmed, S. (2011). Potential antagonistic fungal species from Ethiopia for biological control of chocolate spot disease of faba bean. Afr. Crop Sci. J., 19 (3): 213 - 225.

[44] Scott-Carig, J. S.; Kerby, K. B.; Stein, B. D. and Somerville, S. C. (1995). Expression of an extracellular peroxidase that is induced in barley (Hordium vulgar) by powdery mildew pathogen (Erysiphe graminis f. sp. hordei). Physiol. Mol. Plant Pathol., 47: 407-418.

[45] Shoda, M. (2000). Bacterial control of plant diseases. J. Biosci. and Bioeng., 89:515-521.

[46] Snedecor, G. W. and Cochran, W. G. (1967). Statistical Methods. $6^{\text {th }}$ ed. Iowa State. Univ. Press, Ames, Iowa, USA.

[47] Stoddard, F. L.; Nicholas, A. H.; Rubiales, D.; Thomas, J. and Villegas-Ferna'ndez, A. M. (2010). Integrated pest management in faba bean. Field Crops Res., 115:308-318

[48] Vey, A.; Hoagland, R. E. and Butt, T. M. (2001). Toxic metabolites of fungal biocontrol agents. Fungi as Biocontrol Agents: Progress, Problems and Potential. In: Butt T. M, Jackson C and N, eds., CAB International, Bristol. pp. 311-346. 
[49] Yan, Z.; Reddy, M. S. and Kloepper, J. W. (2003). Survival and colonization of rhizobacteria in a tomato transplant system. Can. J. Microbiol., 49(6):383-389.

[50] Zaher, Effat A.; Abada, K. A. and Zyton-Marwa, A. (2013). Effect of combination between bioagents and solarization on management of crown-and stem-rot of Egyptian clover. Amer. J. of Plant Scis., 1 (3):43 -50.

[51] Zimand, G.; Elad, Y. and Chet, I.(1996). Effect of Trichoderma harzianum on Botrytis cinerea pathogeni-city. Phytopathology, 86: 11, 12551260. 